\title{
California and the Uniform Stock Transfer Act
}

$T^{N}$ THE twenty-one years that have passed since the Uniform Stock 1 Transfer Act was first recommended, ${ }^{1}$ California, despite the adoption of the Act by Alaska and twenty states, has done nothing except to give it a passing glance some eleven years ago. ${ }^{2}$

Among the twenty states ${ }^{3}$ that have made use of the Uniform Act are such commercial and financial leaders as New York, Illinois, Pennsylvama, and Massachusetts, states in which the volume of stock transfers has put the uniform statute through a severe but successful test. In view of the increasing importance of California in the commercial world and of the greater number of holders of corporate stocks and securities resident in this state it is surprising that the investing public should continue to endure statutory rules as to stock transfers that were promulgated at a time when a corporation was generally regarded as a device of dubious virtue utilized by financiers of the fancier variety. ${ }^{4}$

According to the present law in California on stock transfers, it would seem that no purchaser of shares of stock can be certain that he is getting title to the shares unless (1) previous to the purchase he inspects the books of the corporation and finds the title of his transferor clear, ${ }^{5}$ and (2) coincidentally with the purchase he notifies the corporation or its transfer agent and obtains a transfer of the shares into his own name on the stock records of the corporation. ${ }^{6}$

1 The Act was approved by the National Conference of Commissioners on Uniform State Laws in 1909 - see Reports of American Bar Association (1909) 1001.

$2 \mathrm{~A}$ bill incorporating the Act was introduced as Senate Bill No. 421 by Senator Carr, Jan. 23, 1919, and apparently died in Committee on Judiciary to which it was referred on Feb. 25, 1919. The adoption of the Act with some modifications, (1) as to certificates for shares already issued; (2) as to certificates for shares issued by foreign corporations, is proposed in the Third Report of the Committee of the State Bar on Revision of the Corporation Laws. 6 State BAR J. (Jan. 1931) Part II, p. 24.

3 The full list of states which have adopted the Act as given by 6 GREENE, UNJFoRM Laws ANNotated in the 1929 Supplement is: Alaska, Arkansas, Colorado, Connecticut, Idaho, Illinois, Indiana, Louisiana, Maryland, Massachusetts, Michigan, New Jersey, New York, Ohio, Pennsylvania, Rhode Island, South Dakota, Tennessee, Utah, Virginia, Wisconsin.

4 The present CAL. CIv. CODE $\$ 324$, can be traced back in substantially its present form to Cal. Stat. 1850 , p. $342, \$ 12$. See also Cal. Stat. 1853, p. 88, §9; Cal. Stat. 1853, p. 106, §20 (Railroad Corporations); Cal. Stat. 1853, p. 171, \$13 (Plank or Turnpike Road Corporations).

5 See Batlantine, Manuat of Corroration Law and Practice (1930) $\S \S 148,149$, pp. 470,472 .

${ }^{6}$ See infra, page 156. 
Impressed as the average stock purchaser will be by the practical onerousness of these requirements, his wonder and dismay will undoubtedly increase when he attempts to fulfill the first of them and is informed that under the present California statute, he has no right to make such an inspection of the corporate records, ${ }^{7}$ and when he realizes that in spite of his most diligent efforts to fulfill the second of them, there will most likely elapse an interval within which his title niay be defeated.

In the construction and interpretation of the California statutes regulating stock transfers, it nust be admitted that the courts have, in some respects to a considerable extent, ameliorated the position of a stock purchaser or pledgee, but notwithstanding this beneficial judicial legislation, the law today is substantially as stated. Such judicial legislation, however, has caused an undesirable degree of uncertainty. ${ }^{8}$ It was uncertainty of a similar nature ${ }^{9}$ - attributable in part to varying statutes and in part to the efforts of the courts by interpretation, to give the statutes an effect which would be more nearly suitable to the business needs of the community - which was undoubtedly a factor in the approval of the Uniform Stock Transfer Act in 1909 by the National Conference of Commissioners on Uniform State Laws.

The Act is intended primarily to acconiplish two purposes of alniost equal value: First, uniformity; and, second, inmprovenent in the regulation of stock transfers. To acconplish the second purpose, the Act first makes legal title to the shares inseparable from legal title to the certificate evidencing the shares, ${ }^{10}$ and second, gives the certificate

7 CAL. CIv. CoDE \$378, referring to stock records of a corporation, provides: "Such stock and transfer book shall be open to the inspection of any officer, bona fide stockholder, member, or creditor of the corporation."

8 See infra, page 154 .

${ }^{9}$ See the discussion and analyses of Stock Transfer Statutes contained in the following Notes: Rights of Unregistered Transferee as Against Attachment or Execution Levied on Stock, (1910) 21 Ann. Cas. 1394; Delivery of Certificate of Stock Without Endorsement or Registration as Valid Gift, (1911) Ann. Cas. 1912 C, 1235; Validity of Pledge or Other Transfer of Stock of Corporation When Not Made in Books of Company as Against Attachments, Executions or Subsequent Transfers, (1902) 67 L. R. A. 656; see also Note (1908) 20 L. R. A. (N.S.) 996; Priority as Between True Owner and Execution or Attachment Creditors of One in Whose Naine He Has Placed Stock on the Books of the Corporation, (1914) 49 L. R. A. (N.S.) 1159; Validity of Transfers Not Made in Manner Prescribed, (1896) 57 Am. St. Rep. 389.

10 See Uniform Stock Transfer Act, $\$ \S 1$ and 4, reading as follows:

"Section 1. How title to certificates and shares may be transferred. - Title to a certificate and to the shares represented thereby can be transferred only,

(a) By delivery of the certificate indorsed either im blank or to a specified person by the person appearing by the certificate to be tlie owner of the shares represented thereby, or 
certain characteristics of negotiability not now given under the California law. 11 These features of the Act, tending materially to improve

(b) By delivery of the certificate and a separate document containing a written assignment of the certificate or a power of attorney to sell, assign, or transfer the same or the shares represented thereby, signed by the person appearing by the certificate to be the owner of the shares represented thereby. Such assignment or power of attorney may be either in blank or to a specified person.

The provisions of this section shall be applicable although the charter or articles of incorporation or code of regulations or by-laws of the corporation issumg the certificate and the certificate itself, provide that the shares represented thereby shall be transferrable only on the books of the corporation or shall be registered by a registrar or transferred by a transfer agent."

"Section 4. Title derived from certificate extinguishes title derived from a separate document. - The title of a transferee of a certificate under a power of attorney or assignment not written upon the certificate, and the title of any person claiming under such transferee, shall cease and determine if, at any time prior to the surrender of the certificate to the corporation issuing it, another person, for value in good faith, and without notice of the prior transfer, shall purchase and obtain dehvery of such certificate with the mdorsement of the person appearing by the certificate to be the owner thereof, or shall purchase and obtain delivery of such certificate and the written assignment or power of attorney of such person, though contamed in a separate document."

11 See Uniform Stock Transfer Act $\$ \$ 5,6,7$ and 8 , reading as follows:

"Section 5. Who may deliver a certificate. - The delivery of a certificate to transfer title in accordance with the provisions of section 1, is effectual, except as provided in section 7 , though made by one having no right of possession and having no authority from the owner of the certificate or from the person purporting to transfer the title.

"Section 6. Indorsentent effectual in spite of frand, duress, mistake, revocation, death, incapacity or lack of consideration or authority. - The indorsement of a certificate by the person appearing by the certificate to be the owner of the shares represented thereby is effectual, except as provided in section 7, though the indorser or transferor,

(a) was induced by fraud, duress or mistake, to make the indorsement or delivery, or

(b) has revoked the delivery of the certificate, or the authority given by the indorsement or delivery of the certificate, or

(c) has died or become legally incapacitated after the indorsement, whether before or after the delivery of the certificate, or

(d) has received no consideration.

(a) was procured by fraud or duress, or

(b) was made under such mistake as to make the indorsement or delivery inequitable; or

If the delivery of a certificate was made

(c) without authority from the owner, or

(d) after the owner's death or legal incapacity, the possession of the certificate may be reclaimed and the transfer thereof rescinded, unless:

(1) The certificate has been transferred to a purchaser for value in good faith without notice of any facts making the transfer wrongful, or

(2) The injured person has elected to waive the injury, or has been guilty of laches in endeavoring to enforce his rights.

Any court of appropriate jurisdiction may enforce specifically such right to reclaim the possession of the certificate or to rescind the transfer thereof and, pending litigation, may enjom the further transfer of the certificate or impound it. 
the position of a bona fide purchaser or pledgee, will be discussed more fully at a subsequent point.

It is not easy to determine the reasons for California's delay in adopting the Uniform Act. Possibly the Bar of the state was somewhat influenced by an article which appeared nine years ago in this Review, ${ }^{12}$ at a time shortly after the Act had been under consideration by the legislature. The writer of that article reached three general conclusions: First, that the California law on stock transfers is far from being in an unsatisfactory state, and that, consequently, the Uniform Act would have but comparatively slight effect on the rules now governing; ${ }^{13}$ and, second, that those changes which would be made by the Act relating to transfer of title may be disadvantageous, if not actually dangerous, to the average investor ${ }^{14}$ and third, that many trouble-situations confronting those whose business it is to deal in stock transfers are not met by the Act. ${ }^{15}$

In estimating the soundness of the conclusion as to the satisfactory state of the present law in this state on stock transfers, it is desirable to consider the existing Califormia law on stock transfers:

NEGotIABIIITy: There being no statutory declaration that stock certificates are negotiable, it has been held, from the time of the earlier decisions on the question, that a stock certificate is not negotiable. ${ }^{16}$ In fact, non-negotiability of stock certificates, from one's first examination of the cases, would appear to be beyond question, ${ }^{17}$ but even on this point there is evidence of judicial wavering, ${ }^{18}$ and more recently

\footnotetext{
"Section 8. Rescission of transfer of certificate does not invalidate subsequent transfer by transferee in possession. - Although the transfer of a certificate or of shares represented thereby has been rescinded or set aside, nevertheless, if the transferee has possession of the certificate or of a new certificate representing part or the whole of the same shares of stock, a subsequent transfer of such certificate by the transferee, mediately or immediately, to a purchaser for value in good faith, without notice of any facts making the transfer wrongful, shall give such purchaser an mdefeasible right to the certificate and the shares represented thereby."

12 Seymour, The Proposed Uniform Stock Transfer Act (1921) 9 CALIF. L. REv. 186.

13 Seymour, op. cit. supra note 12 , at 186.

14 Seymour, op. cit. supra note 12, at 187, 188.

15 Seymour, op. cit. supra note 12, at 187.

16 Sherwood v. Meadow Valley Mining Co. (1875) 50 Cal. 412, holding that bona fide purchaser from finder of certificate endorsed in blank, acquires no title to the shares. Craig v. Hesperia Land and Water Co. (1896) 113 Cal. 7, 45 Pac. 10.

${ }_{17}$ O'Dea v. Hollywood Cemetery Assn. (1908) 154 Cal. 53, 97 Pac. 1; Perkins v. Cowles (1910) 157 Cal. 625, 108 Pac. 711; Powers v. Pacific Diesel Engine Co. (1929) 206 Cal. 334, 274 Pac. 512. See Note (1929) 17 CaLIF. L. Rev. 403.

18 In Winter v. Belmont Mining Co. (1879) $53 \mathrm{Cal}$. 428, 431, it appeared that one $W$ had caused shares to be transferred to, and new certificates issued in the name of, $M$ as trustee, with' the understanding that $M$ should indorse the certificates in blank and return them to $W$, wbich he did. Then $M$. stole the
} 
the judges have occasionally made utterances that cause one to wonder. ${ }^{19}$ This degree of uncertainty on what should be fundamental can hardly be deemed satisfactory.

From an early date, courts have avoided the logical conclusions in particular cases resulting from a strict observance of the rule of nonnegotiability of stock certificates, by a resort to the rule which has come to be generally known as the "McNeil rule," or the "rule of McNeil v. Tenth National Bank," 20 that if one of two innocent persons must suffer from the wrongdoing of a third person in transferring a stock certificate, the one who made possible the commission of the wrong should suffer. The most common situation for the application of the rule is that in which $A$ endorses certificates in blank and delivers

certificates and sold them to a bona fide purchaser. The court held for the latter, relying on the later opinion in Weston v. Bear River and Auburn Water and Mining Co. (1856) $6 \mathrm{Cal}$. 425, to the effect that a bona fide purchaser of shares at an execution sale prevails over a prior pledgee, and saying on page 431 , with reference to that opinion: "The Court reached this conclusion solely on the theory that the statutes regulating the transfer of certificates of stock in a private corporation imparted to the certificates, as between third persons, the character of negotiable instruments." On page 432, the court continued, not without reason, "Assuming that decision [the Weston case] to be correct, the principle which it decides is not distinguishable from that involved in this case. If the purchaser in good faith and without notice ... [at execution sale prevails] certainly a purchaser at private sale in good faith and without notice, in the usual course of business, of a certificate issued to the registered owner and duly endorsed by him ought to stand on at least as favorable a footing."

Four years later, the court in Barstow v. Savage Mining Co. (1883) $64 \mathrm{Cal}$. 388, 1 Pac. 349, mvolving substantially similar facts, rejected the Winter case, and returned to the rule of non-negotiability, attempting to explain the Winter case by an application of the rule in McNeil v. Tenth National Bank (1871) 46 N. Y. 325, 7 Am. Rep. 341.

10 In Graves v. Mono Lake Hydraulic Mining Co. (1889) 81 Cal. 303, 325, 22 Pac. 665, 672, the court said: "But it seems to be settled that certificates of stock endorsed im blank by the owners to whom they issued, pass by mere delivery, without further indorsement, and without transfer on the books of the corporation, although they are not negotiable securities in the commercial sense, or within the definition of the Civil Code." This holding, however, does not serve to make them negotiable in the sense that equities in favor of the owner are cut off by the delivery of a certificate to bona fide purchaser.

In 1928, the court, in Powers v. Pacific Diesel Engine Co. (1929) 205 Cal. 334, 340, 274 Pac. 512, 514, stated: "It is not questioned that stock certificates under the law of this state are not negotiable in the strict sense, but that by the customs of the trade one of the attributes of negotiability, viz.: the passing of title to shares of stock by indorsement in blank and delivery of the certificate, has been given to such certificates." (Italics added.)

20 Froun McNeil v. Tenth National Bank (1871) 46 N. Y. 325, 7 Ain. Rep. 341 , considered the leading case enunciating the rule. See Ballantine, Manued of Corporation Law and Practice (1930) \$\$149, 150, pp. 474, 476.

This rule was applied early in the case of Brewster v. Sime (1871) $42 \mathrm{Cal}$. 139. $O$ transferred shares into name of $T$ as trustee and had new certificates so issued, with which he entrusted $T$; $\mathrm{m}$ violation of the trust $T$ endorsed the certificates as trustee and sold them to a bona fide purchaser. 
them to $B$ as a pledge securing a particular loan, and $B$, in violation of the pledge terms, sells and delivers the certificates to $C$, a bona fide purchaser, for value without notice of the pledge. In accordance with the $\mathrm{McNeil}$ rule $C$ is protected. The California courts have followed this rule for years, ${ }^{21}$ and one could not have been blamed for feeling that the law, in this respect, was satisfactory. Its application appeared to be clear - until in a recent case the Supreme Court in banc within a year reversed its decision in department upon the applicability of the McNeil rule.22 The unanimity of the reversal is the more surprising in view of the fact that in the earlier opinion, the court liad not. only denied appellant's contention that the McNeil rule was applicable, but also fined him $\$ 100.00$ for prosecuting a frivolous appeal. The result reached in the later decision appears to be sound from the point of view of policy, but it is difficult to find satisfaction in a state of law in which the Supreme Court disagrees with itself so completely within a year as to the application of what had appaprently come to be considered a well established rule. Such judicial divination, it may be observed, is a not unusual concomitant of statutory insufficiencies,

21 Thompson v. Toland (1874) $48 \mathrm{Cal}$. 99. Facts similar to those in the Brewster case.

Arnold v. Johnson (1885) 66 Cal. 402, 5 Pac. 796. $O$ had entrusted certifcates endorsed in blank to $D$ for the purpose of exchanging them for new certificates from the corporation, and $D$ sold them to a bona fide purchaser.

Brittan v. Oakland Bank of Savings (1899) 124 Cal. 282, 57 Pac. 84, 71 Am. St. Rep. 58; Fowles v. National Bank of California (1914) 167 Cal. 653, 140 Pac. 271; Hellman Coinmercial Trust and Savings Bank v. Armstrong (1919) 39 Cal. App. 483, 179 Pac. 432 - repledge without authority by first pledgee; Mancini v. Setaro (1924) 69 Cal. App. 748, 232 Pac. 495. In none of these cases involving unauthorized dealings by pledgees is there any mention of a notation of the pledge on the corporate books. In a case where it appeared that such notation had been made, would a bone fide purchaser or pledgee, in view of the McNeil rule, be held to be bound by constructive notice of the notation on the books, in accordance with the rule in Spreckels v. Nevada Bank of San Francisco (1896) 113 Cal. 272, 45 Pac. 329, 54 Am. St. Rep. 348, 33 L. R. A. 459.

22 Powers v. Pacific Diesel Engme Co. (1929) 206 Cal. 334, 274 Pac. 512; noted in (1929) 17 CALIF. L. REv. 403. The evidence showed that an elderly woinan had been defrauded into entrusting her certificates endorsed in hlank to two men who represented themselves to be officers of the issuing corporation. The certificats wre sold to a bona fide purchaser. The decision in the lower court favored the woman, on the grounds that the certificates were not negotiable and no title had passed. On appeal to the Supreme Court in department, appellant's claim that the McNeil rule apphed was considered so absurd that appellant was fined $\$ 100.00$ for a frivolous appeal ((1928) 75 Cal. Dec. 611, 266 Pac. 801). A hearing before the whole court having heen ohtamed, a second opinion was handed down a year later, upholding the contention of appellant as to the applicability of the McNeil rule, on the strength of certain Massachusetts decisions, unearthed in the meantime by diligent counsel, favoring the bona fide purchaser on an extension of the McNeil rule on the basis of estoppel, which only Mr. Justice Holmes, then Chief Justice of Massachusetts, could have made appear so theoretically sound. 
which in this case would to a large extent be met by the adoption of the Uniform Stock Transfer Act under which the negotiability of the stock certificate is made clear and unequivocal and the bona fide purchaser is always protected.

Transfers: (a) Formal Requisites - The Civil Code states that shares of stock may be transferred by endorsement and delivery of the certificates. ${ }^{23}$ But it has been held, on more than one occasion, that this statement is permissive only, and not exclusive, and that shares may be transferred by assignment, or bill of sale or by any other means by which intangible property may be transferred. ${ }^{24}$ In other words, there is no necessary relation between title to the shares and title to or possession of the certificates. ${ }^{25}$

(b) Effect as to Third Parties - Attachment. - The Civil Code provides further, however, that the transfer is not valid except as to the immediate parties thereto, until it is entered on the books of the corporation. ${ }^{26}$ It is this provision that is most responsible for the unfortunate state of the law on stock transfers, when considered, as it most often has been, in connection with the section of the Code of Civil Procedure which permits attachment of shares standing in the name of the defendant on the corporate books, by simply leaving a copy of the writ at the office of the issuing corporation. ${ }^{27}$

23 CAL. Crv. CoDE, \$324. "Transfer of shares of stock. Certain stock appurtenant to land. Whenever the capital stock of any corporation is divided into shares, and certificates therefor are issued, such shares of stock, except as hereinafter provided, are personal property, and may be transferred by indorsement by signature of the proprietor, bis agent, attorney, or legal representative, and the delivery of the certificate; but such transfer is not valid, except as to the parties thereto, until the same is so entered upon the books of the corporation as to show the names of the parties by wbom and to whom transferred, the number of the certificate, the number or designation of the shares, and the date of the transfer ..."

24 Hall v. Cayot (1903) 141 Cal. 13, 74 Pac. 299; Young v. New Pedrara Onyx Co. (1920) 48 Cal. App. 1, 192 Pac. 55; Bacon v. Traders Oil Corporation (1921) 52 Cal. App. 172, 201 Pac. 477; Mancini v. Setaro (1924) 69 Cal. App. 748, 232 Pac. 495; Delannoy v. Quetu (1925) 73 Cal. App. 627, 239 Pac. 71. But cf. Tafft v. Presidio and Ferries R. Co. (1890) 84 Cal. 131, 24 Pac. 436, 18 Am. St. Rep. 166, 11 L. R. A. 125.

25 See Cortelyou v. Imperial Land Co. (1909) 156 Cal. 373, 104 Pac. 695, holding that a transferee of shares was entitled to the issuance of new certificate by the corporation even though he had not possession of the old certificate; and Tregear v. Etiwanda Water Co. (1888) 76 Cal. 537, 18 Pac. 658, 9 Am. St. Rep. 245 , holding that a inortgagee of shares who bad permitted the mortgagor to retain possession of the certificate, was entitled to a new certificate upon purchasing the sbares himself at foreclosure sale.

26 CaL. CIv. CoDe, §324, see supra, note 23.

27 CaL. Code Civ. Proc., §542: "How real and personal property shall be attached. The sheriff to whom the writ is directed and delivered, must execute 
If the Civil Code means what it says, the entry of the transfer on the corporate books would appear to be necessary to complete the transferee's legal title, and any third party who first perfects his title to the same shares would prevail, regardless of notice of the transferee's prior claim. The California court, however, early found itself unable to make it so easy to defraud prior transferees and held that the only sort of third party who could defeat the interest of a prior unregistered transferee was a bona fide purchaser without actual notice of the transferee's claim, and that therefore a purchaser at execution sale with actual notice of such a claim took nothing as against the transferee. ${ }^{28}$

In later opinions there was some grumbling at this judicial legislation, ${ }^{29}$ but it has come to be well established law. ${ }^{30}$

The court refused, however, to hold that the phrase "third parties"

the saine without delay, and if the undertaking mentioned in section five hundred forty [of this code] be not given, as follows:

"4. Stocks or shares, or interest in stocks or shares, of any. corporation or company, must be attached by leaving with the president, or other head of the same, or the secretary, cashier, or other managing agent thereof, a copy of the writ, and a notice stating that the stock or interest of the defendant is attached, in pursuance of such writ."

28 Weston v. Bear River \& Auburn Water and Mining Co. (1855) 5 Cal. 186, (1856) $6 \mathrm{Cal}$ 425, 429. In the second case the court said: "A party who purchases at sheriff's sale, stock of an incorporation, knowing that the certificates of such stock have been previously hypothecated, is chargeable with notice of such fact, and takes subject to the claim of the pledgee. Neither the incorporation law of 1850 , or of 1853 , was intended to cover a case of this kind, but apply only to transfers and purchases in good faith without notice."

The first decision, holding transfer as not valid until registered on the books, did not contain a statement of facts. The court in the second decision stated, at page 430, that the point having reference to the notice of attaching creditor was not presented for the consideration of the court at the time of the first case.

29 In Naglee v. Pacific Wharf Co. (1862) 20 Cal. 529, 533, the court protected the corporation against the demand by the assignee of the original owner for transfer where it appeared that the corporation had inade a trausfer to a third party of a certifieate of stock bought for value in good faith at an execution sale in a suit against the assignor. The court reluctantly following the Weston decisions, saying: "It may not be quite clear upon what principle that distinction rests. If by the operation of the statute, the transfer was absolutely void against all persons except the parties, and for that reason was void against the rights of an attaching creditor - which is the decision in the case in the 5th Cal. - there seems to be some difficulty in saying that this right of the attaching creditor can be defeated by giving him notice after his lien has attached, or giving bidders at the sale notice of a prior transfer; but this is the effect of the decision in the 6th Cal."

See also People v. Elinore (1868) 35 Cal. 653, and Parrott v. Byers (1871) 40 Cal. 614.

30 Blakeman v. Puget Sound Iron Co. (1887) 72 Cal. 321, 13 Pac. 872; West Coast Safety Faucet Co. v. Wulff (1901) 133 Cal. 315, 65 Pac. 622; American Trust \& Banking Co. v. Union Security Co. (1919) 43 Cal. App. 126, 184 Pac. 508; Security Coinmercial and Savings Bank v. Imperial Water Co. No. 1 (1920) 183 Cal. 488, 192 Pac. 22; Jackins v. Queen Oil Co. (1921) 184 Cal. 645, 195 Pac. 51. 
could be expanded to cover the case of an attaching creditor who was bona fide and without notice of a prior unentered transfer, at the time of attachment, but who acquired notice through the entry of the transfer prior to the execution sale. ${ }^{31}$

If, then, a creditor at execution sale without notice of a transfer which preceded his attachment, but was unentered, can prevail over the transferee, it would seem to follow, a fortiori, that if $O$, the owner of shares standing in his name on the corporate records, endorses and delivers the certificates to $A$ for a present consideration, and one-half hour later assigns the same shares to $B$, likewise for a present consideration ( $B$ having no notice of the transfer to $A$ ), and $B$ is the first to present his assignment to the corporation and request it to transfer the shares into his name, he will prevail over $A . B$ is a bona fide purchaser, without notice, for a present value; so far as formal requisites go, his assignment is as effective a transfer as the endorsement and delivery of the certificate, and he has been the first to present his assignment and request a transfer. The fact that the corporation may have a by-law stating that its shares are transferable only upon surrender of the certificate (which is probably also printed on the certificate) is material as between the corporation and its shareholders, but is without significance as between $A$ and $B .^{32}$

To add to the embarrassment of a stock purchaser, the Spreckels

31 National Bank of the Pacific v. Western Pacific Ry. Co. (1910) 157 Cal. 573, 108 Pac. 676. See an excellent discussion of the Weston opinions and cases immediately following thein on pages 576-580; the court reasoned from the materiality of notice in the case of an execution purchaser that an unentered transfer must convey the interest in the shares to the transferee, and therefore there is nothing for the attachment to reach. The decision is probably sound in the light of the Weston case and those which followed it.

32 The stateinent made by Seymour, op. cit. supra, note 12 at 193 that "It seems unquestioned, therefore, that between the parties title to stock may be transferred without delivery of the certificate. It seems, too, to admit of little doubt but that California courts would protect an intervening bona fide purchaser of the certificate, were the case presented to them, just as the Uniform Act does in so many words." is thus obviously subject to the qualification that a bona fide purchaser of the certificate, in order to prevail, must be the first to give notice of his rights to the corporation. See National Bank of the Pacific v. Western Pacific Ry. Co. (1910) 157 Cal. 573, 582, 108 Pac. 676, 680, where it is said: "The certificate liere in question recited that it was transferable only on the books of the company and on surrender of the certificate. This did not affect the transfer. The right to sell, transfer, or pledge corporation stock is given by statute and it cannot he curtailed by a recital in the certificate. The recital served to give notice of the rights of the corporation under the statute, with respect to transfers, but it did not change the relative rigbts of the stockholder and third persons, with respect to each other, nor make the unregistered transfer subject to the attachment lien."

Seè also Riverside Land Co. v. Jarvis (1917) 174 Cal. 316, 163 Pac. 54, and Harvey v. Stowe (1914) 219 Fed. 17; affd. (1916) 241 U. S. 199. 
case $^{33}$ holds that a subsequent purchaser or pledgee of shares is bound by constructive notice of a notation of pledge made on the corporate books by a prior pledgee, and as a result of such constructive notice the rights of the subsequent purchaser or pledgee are declared to be subject to the pledge so previously noted..$^{34}$ The absurdity of this rule has been indicated above, and has been pointed out in at least one subsequent case. ${ }^{35}$ Under the present statute, a subsequent purchaser or pledgee has no right to inspect the corporate records, unless he is already a shareholder or creditor of the corporation. ${ }^{36}$ In other words, the subsequent purchaser or pledgee is deemed to have constructive notice of a record which he has no right to inspect.

33 Spreckels v. Nevada Bank of San Francisco (1896) 113 Cal. 272, 45 Pac. 329,54 Am. St. Rep. 348, 33 L. R. A. 459. Uncertainty, however, is added to the rule by a dictum in the later case of Hall v. Cayot (1903) $141 \mathrm{Cal} .13,17,74 \mathrm{Pac}$. 299,301 , to the effect that "as delivery of possession is essential to the validity of a pledge, a delivery of the certificate without a transfer in writing which will enable the holder to make a transfer of the stock to his own name on the books of the corporation is not a complete delivery, for it does not place the stock in the full control of the pledgee."

The Spreckels case also holds that the pledgee has no right to have stock transferred to his name in the absence of contract.

34 In the Spreckels case, (1896) 113 Cal. 272, 277, 45 Pac. 329, 331, 54 Am. St. Rep. 348, 351, 33 L. R. A. 459, 461, it was said: "All that section 324 of the Civil Code exacts of a pledgee, for the protection of his interests, is that he should cause the transaction and the naturd of it to be so entered upon the books of the corporation as to show the names of the pledgor and the pledgee, the namber or designation of the shares, and the date of the transfer. All this may be done to the full protection of the pledgee's rights without the surrender of the certificates, their cancellation, and the issuance to him of new ones, and, when done, the pledgee would be fully protected against a subsequent purchaser, who would be clarged with the constructive notice which the entries upon the books of the corporation import; and, upon the other hand, there would be preserved to the pledgor all the rights incident to his ownership under the pledge."

35 In National Bank of the Pacific v. Western Pacific Ry. Co. (1910) 157 Cal. 573, 581, 108 Pac. 676, 679, the court said: "It may be remarked further that the reason given, as above stated, in the first Weston case, for the rule there adopted, had no foundation in the law then in force and has none under the present law. It was founded on the notion that 'the stock and transfer book' of a corporation is made a public record, accessible to all persons, imtended to give notice to everybody of the status and ownership of the title to the stock, and that it is therefore available to the creditors of the stockholders and to persons dealing with them with respect to the stock. This is the law of some of the states where the rule contended for by the defendant prevails, but it is not the law of this state. (Civ. Code, sec. 378). It was not the law with respect to mining corporations at the time the Weston cases were decided. (Stats. 1850, p. 368, sec. 144; Stats. 1853 , p. 90 , sec. 18). The creditors of the individual stockholders have no such right of access, and the books could not constitute notice to them. Nor could these books hold any person out to the world as the owner of any stock, since the world could not liave access thereto. Stockholders and creditors of the corporation are the only persons who have the right to inspect the books. (Civ. Code, sec. 378)."

36 CAL. Civ. Code \$378, quoted supra note 7. 
Furthermore, a subsequent transferee is held to be bound by a prior attachment levied against his transferor ${ }^{37}$ - a result which, unfortunate as it may be, seems to follow logically from the constructive notice rule enunciated in the Spreckels case, the only redeeming factor being the probability that a diligent prospective transferee could, by the expenditure of considerable effort, determine whether or not a writ of attachment against the transferor or his predecessor had previously been left with the corporation. The particular viciousness of the Ramage decision is its holding that a transferee after prior attachment levied against his transferor can compel the issuance of a new certificate which will give no notice of the attachment lien - and even an inspection of the books would be of no avail (since the attachment is not against the transferee) unless the bona fide purchaser from the transferee examines the full chain of title, which he has no right to do. Thus, the risks to a bona fide purchaser are manifoldly increased. The only answer the court makes to this is:

"If as is contended, this conclusion makes it possible for the owner of shares which have been attached to deceive others by inducing them to purchase shares in ignorance of the levy, the remedy lies with the legislature." 38

It would appear then from the foregoing discussion that there is some foundation in the cases for the statement made above that the title of a purchaser of shares of stock in California is, regardless of the fact that he proposes to obtain or may have obtained delivery of properly endorsed certificates, subject to the following risks against which there is in all cases no practicable protection, and in at least two cases ((a) and (b)) no legal protection: (a) An attachment may have theretofore been levied against his transferor by the leaving of a copy of the writ at the office of the corporation; (b) his transferor may have made a prior pledge of the shares, and the pledgee's interest noted on the books of the corporation; his transferor may theretofore have made, or may thereafter make (c) an assignment or (d) a pledge of the same shares, which may be entered first on the corporation books, or notice of which may be first given to the corporation; or (e) before he gives notice to the corporation or effects a transfer on its books, the shares may be sold on execution sale as a result of an attachment or execution levied before or after the transfer.

If it has been sufficiently demonstrated that the California law on stock transfers is in an unsatisfactory state because of its uncertainty

37 Ramage v. Gould (1917) $176 \mathrm{Cal}$. 746, 169 Pac. 670. To same effect see Bowring v. Prime (1920) 46 Cal. App. 538, 189 Pac. 701.

38 Ramage v. Gould (1917) 176 Cal. 746, 751, 169 Pac. 670, 671. 
in several respects, ${ }^{39}$ and the undesirability of the results effected by such rules as can be adduced from decided cases, it may be appropriate to discuss the changes which would be brought about by the Uniform Act and the advantages of such changes.

NEGoTIABILITY: Under the Uniform Act a stock certificate clearly assumes as to the transfer of title all the attributes of negotiability. ${ }^{40}$ Good title to a certificate endorsed in blank by the issuee may be transferred to a bona fide purchaser for value by any person having possession of the endorsed certificate, including a finder or a thief. Such a rule is obviously advantageous from the purcliaser's viewpoint, althougl

39 There are other uncertain points in the California law on stock transfers, which may be mentioned, e.g., the character, legal or equitable, of a pledgee's interest. In North-Western Portland Cement Co. v. Atlantic Portland Cement Co. (1917) 174 Cal. 308, 163 Pac. 47, it was held that a pledgee to whom the certificates have been delivered and endorsed, but who has not caused a notation of the pledge to be made on the corporate books, has a legal rather than an equitable interest, or special property. The court referred to the analogy to land registration statutes, saying on page 314 (163 Pac. at page 50) with reference to Section 324 of the Civil Code: "The effect of this provision, as construed by this court, is analogous to that of the statutes with reference to the recording of instruments affecting real property. The dehvery of the indorsed certificate passes title, but such title cannot be asserted against purchasers or encumbrancers who have no notice of the transfer."

See also Young v. New Pedrara Onyx Co. (1920) 48 Cal. App. 1, 192 Pac. 55.

In Hall v. Cayot (1903) 141 Cal. 13, 18, 74 Pac. 299, 301, on the other hand, the court indicated that a pledgee to whoin certificates had been delivered unendorsed has an "equitable title to the shares which may be enforced in equity as between the parties." In Herbert Kraft Co. Bank v. Bank of Orland (1901) 133 Cal. 64, 65 Pac. 143, the court did not determine whether the pledgee's interest is legal or equitable, saying that in either case the pledgee had sufficient interest to maintain an action against the corporation for forfeiture of the shares on a void assessment, and in Cross v. Eureka Lake and Yuba Canal Co. (1887) 73 Cal. 302, 14 Pac. 885, in answer to the claim that legal title to the shares had passed to a pledgee, the court said on page 306 (14 Pac. at 887): "This claim cannot be maintained. Sigourney was only the pledgee of the stock and as between him and the pledgor, the general property remained in the latter." In this connection see also Brewster v. Hartley (1869) $37 \mathrm{Cal} .15,25$, cited in the Cross case, indicating that "apparent legal title" might pass to pledgee, but that as between them, the "general property" remains in the pledgor.

Of historical interest only is Ede v. Johnson (1860) 15 Cal. 53, holding valid a mortgage of shares under the Chattel Mortgage Act of 1857 , despite a failure to comply with the procedure of delivery of certificate and transfer on the books set forth in the Corporation Act of 1853.

And as to the character of a transferee's interest prior to the entry of his transfer on the corporate books, see Northwestern Portland Cement Co. v. Atlantic Portland Cement Co. (1917) $174 \mathrm{Cal}$. 308, $163 \mathrm{Pac}$. 47, in which there appears a dictum to the effect that such a transferee acquires legal title. The earlier California cases appear to establisll clearly the doctrine that the interest of a transferee, prior to registration, is equitable only. See Note Ann. Cas. 1912C, 1235.

40 Ballantine, manual of Corporation Law and Practice (1930) \$148, p. 468. See $\S \S 5,6,7$ and 8 of Uniform Stock Transfer Act, quoted supra note 11. 
not perhaps so beneficial to the owner who has been unfortunate enough, or careless enough, to lose possession of his endorsed certificate. But in view of the volume of dealings in shares of stock, the sounder pohicy seems unquestionably to be that of protecting the great stock purchasing public that perforce cannot help itself, whereas the individual shareholder can, with no particular difficulty, accustom himself to treating a stock certificate with the same care with which he treats his bonds or promissory notes.

TRANSFERS: (a) Formal Requisites-A transfer of legal title to shares of stock can be accomplished under the Uniform Act only by a delivery of the certificate either endorsed or accompanied by separate instrument of transfer. ${ }^{41}$ This requirement of possession of the certificate can hardly be objected to in view of the fact that it is the general practice of cautious purchasers of stock today to request a dehivery of the certificates properly endorsed.

(b) Effect of Transfer - Attachment - The effect of the Uniform Act in making the legal title to the shares inseparable from the legal title to the certificate evidencing the shares is to eliminate the uncertainties and the risks that are attendant upon the purchase of stock under the present California law, as demonstrated earlier in this article. Under the Uniform Act, the purchaser or pledgee of stock, if he be bona fide and without actual notice, can be assured that his title is perfect when he obtains the certificates properly endorsed.

The attaching creditor under the Act is reheved from the uncertainties resulting from the Ramage decision ${ }^{42}$ and the National Bank v. Pacific Railway Company decision. ${ }^{43}$ The procedure, however, for attachment will not be as easy as the existing law provides.44

In cases of rescission the Act also protects the bona fide purchaser. ${ }^{45}$

41 See Uniform Stock Transfer Act, \$1, quoted supra note 12.

42 See supra note 37.

43 See supra note 31.

44 See Uniform Stock Transfer Act, \$\$ 13 and 14, as follows:

"Section 13. No attachment or levy upon shares unless certificate surrendered or transfer enjoined. - No attachment or levy upon shares of stock for which a certificate is outstanding shall be valid until such certificate be actually seized by the officer making the attachment or levy, or be surrendered to the corporation which issued it, or its transfer by the holder be enjomed. Except where a certificate is lost or destroyed, such corporation shall not be compelled to issue a new certificate for the stock until the old certificate is surrendered to it.

"Section 14. Creditor's remedies to reach certificate.-A creditor whose debtor is the owner of a certificate shall be entitled to such aid from courts of appropriate jurisdiction, by mjunction and otherwise, in attaching such certificate or in satisfying the claim by means thereof as is allowed at law or in equity, in regard to property which cannot readily be attached or levied upon by ordinary legal process."

45 See Uniform Stock Transfer Act, §8: 
The writer in the Review ${ }^{46}$ concluded, among other things, that the Uniform Act would not be of material aid to those whose business it is to handle stock transfers. No contention is made that the Act is a panacea for all the problems in the law of stock transfer, but it is natural to believe that any clarification and simplification of the law on this subject will be of substantial advantage to corporations and to transfer agents, and apparently this view is shared by such agents themselves.

In conclusion the writers feel that the adoption of the Uniform Stock Transfer Act by California would not only bring the California practice in line with those of other leading commercial states, but would also remove many undesirable risks to which transferees of stock in California are subjected under the present California law.

\author{
Homer D. Crotty, \\ Graham L. Sterling, Jr.
}

Los Angetes, Cactrorras.

\footnotetext{
"Section 8. Rescission of transfer of certificates does not invalidate subsequent transfer by transferee in possession. - Although the transfer of a certificate or of shares represented thereby has been rescinded or set aside, nevertheless, if the transferee has possession of the certificate or of a new certificate representing part or the whole of the same shares of stock, a subsequent transfer of such certificate by the transferee, mediately or immediately, to a purchaser for value in good faith, without notice of any facts making the transfer wrongful, shall give such purchaser an indefeasible right to the certificate and the shares represented thereby."

46 Seymour, loc. cit. supra note 12.
} 